\title{
Milk protein detection in raw and cooked meat products using immunochemichal methods
}

\author{
Cellerino Karina ${ }^{1}$, Binaghi María Julieta ${ }^{1}$, Cagnasso Carolina Elisa ${ }^{1}$, Docena Guillermo ${ }^{2}$, \\ Lopez Laura Beatriz ${ }^{1}$
}

${ }^{1}$ Food Chemistry, Faculty of Pharmacy and Biochemistry, University of Buenos Aires, Junín 956, CP 1113, Buenos Aires, Argentina

${ }^{2}$ LISIN, Faculty of Exact Sciences, National University of La Plata

\section{Email address:}

kcellerino@ffyb.uba.ar (K. Cellerino)

\section{To cite this article:}

Cellerino Karina, Binaghi María Julieta, Cagnasso Carolina Elisa, Docena Guillermo, Lopez Laura Beatriz. Milk Protein Detection in Raw and Cooked Meat Products Using Immunochemichal Methods. Journal of Food and Nutrition Sciences. Vol. 2, No. 5, 2014 , pp. $236-242$. doi: 10.11648/j.jfns.20140205.16

\begin{abstract}
The aim of this study was to evaluate different immunochemical methods (Dot Blot, Immnoblotting and two different ELISA kits) for the detection of milk proteins in eleven raw and cooked model systems of meat products with 0 $5000 \mathrm{ppm}$ of powder deffated milk (PDM) and in nine raw and cooked model systems of meat products with $0-2000$ ppm of dry whey (DW) and in eleven commercial meat products. All the samples were analysed with Dot Blot and Immunoblotting with specific polyclonal rabbit serum against milk proteins and with two ELISA kits: Veratox ${ }^{\circledR}$ Total Milk Allergen Quantitative Test from Neogen and Ridascreen ${ }^{\circledR}$ Fast Milk from R-Biopharm. ELISA methods are more sensitive for the detection of milk proteins than Dot Blot and Immunoblotting. The R-Biopharm kit was the most sensitive kit for the analysis of these samples. However Immunoblotting can be useful for the detection of milk proteins if it is suspected that they were added as ingredients or additives. Immunoblotting allows to verify the presence of caseins and / or $\beta$-lactoglobulin. In contrast, the use of an ELISA kit is more appropriate to verify a possible cross-contamination.
\end{abstract}

Keywords: Allergens, Milk, Meat Products, ELISA, Dot Blot, Immunoblotting

\section{Introduction}

Food allergy is an abnormal immune response to a food or a food component. The prevalence is higher in children $(6$ $-8 \%)$ than in adults $(2 \%)$ [1]. There are eight food groups that are responsible for $90 \%$ of food allergies: milk, egg, soy, wheat, peanuts, tree nuts, fish and shellfish. A second group of allergenic foods has been defined; they are the "second big eight": mustard, sesame, sunflower, cotton, molluscs, lentils, peas and poppies [2-5].

In the manufacture of meat products often extrinsic proteins, such as bovine or porcine plasma, soy products, different dairy products (caseinate, whey, powder deffated milk, etc), collagen, gelatin, etc. are used [6]. These proteins work as water retention agents and emulsifying fats, they are good coagulants during cooking and improve shine and moisture of the product. Some of the proteins previously mentioned are food allergens and therefore constitute a risk for allergic patients, mainly when these proteins are not declared as ingredients in the food labels. According to the
Argentine Food Code, all the ingredients used must be declared on the label [7]. However in some products undeclared protein ingredients can be detected [8].In Argentina the mandatory declaration of allergens in food labels is under revision [7].

There is a need of methodology that enables the detection of extrinsic allergenic proteins in meat products. The most common methodology for the analysis of food allergens is ELISA. Commercial kits are available from different companies. However the cost of these kits in Argentina is very high.

The aim of this study was to evaluate different immunochemical methods (Dot Blot, Immunoblotting and two different ELISA kits) for the detection of milk proteins in raw and cooked model systems of meat products with powder deffated milk (PDM) and dry whey (DW) and in commercial meat products. 


\section{Materials and Methods}

\subsection{Model Systems of Raw Meat and Cooked Boneless Ham}

Eleven model systems of raw meat with the addition of PDM were prepared in the laboratory. The models systems were: $0 ; 10 ; 17.5 ; 25 ; 50 ; 100 ; 500 ; 1000 ; 2000 ; 3000$ and 5000 ppm of PDM in mixture with raw meat.

Nine model systems of raw meat with addition of dry whey (DW) were prepared in the laboratory. The model systems were: $0 ; 10 ; 17.5 ; 25 ; 50 ; 100 ; 500 ; 1000$ and 2000 ppm of DW in mixture with raw meat.

Eleven model systems of cooked boneless ham with the addition of PDM were prepared in the laboratory. The models systems were: $0 ; 10 ; 17.5 ; 25 ; 50 ; 100 ; 500 ; 1000$; 2000; 3000 and 5000 ppm of PDM in cooked boneless ham.

Nine model systems of cooked boneless ham with the addition of DW were prepared in the laboratory. The models systems were: $0 ; 10 ; 17.5 ; 25 ; 50 ; 100 ; 500 ; 1000$ and $2000 \mathrm{ppm}$ of DW in cooked boneless ham.

These model systems were prepared in duplicate mixing different quantities of minced cooked boneless ham with $0.5 \%$ (5000 ppm) of PDM with minced cooked boneless ham without extrinsic proteins for the first group and different quantities of minced cooked boneless ham with $0.2 \%$ (2000 ppm) of DW with minced cooked boneless ham without extrinsic proteins for the second group. The cooked boneless ham with $0.5 \%$ of PDM, the cooked boneless ham with $0.2 \%$ of DW and the cooked boneless ham without extrinsic proteins were manufactured by a local industry. The weight of each boneless ham was 3.5 $\mathrm{Kg}$ and they were cooked by the system "cook in" in an oven with steam during 4:30 hs, the temperature in the center of each boneless ham reached $72^{\circ} \mathrm{C}$. Each cooked boneless ham was ground in a food processor.

The PDM and the DW were commercial samples and they contain $34.4 \%$ and $74.1 \%$ of proteins, respectively.

\subsection{Commercial Meat Products}

Eleven commercial meat products were analyzed: mortadellas (MP, MPA), boneless ham (JC), porcine products labelled "Fiambre de cerdo" (F, FL, FSL), hamburguer (MCC) and sausages $(\mathrm{CH}, \mathrm{LC}, \mathrm{S}, \mathrm{M})$. A single batch of each product was analyzed. All the content of the package was homogenized in the samples MP, MPA, JC, F, FL, FSL, CH, LC y M. In the case of MCC and S, as each pack contained several units of the product, the sample was prepared mixing a random portion of each unit. Each commercial meat products was ground in a food processor.

\subsection{Treatment of Samples for Dot Blot and Immunoblotting Analysis}

Defatted / dehydrated samples: The samples were slurried in 1/10 ratio with acetone and homogenized in VirTis Model 23 at low speed for 5 minutes. Then they were centrifuged at $1200 \mathrm{rpm}$ for 20 minutes and the supernatant was discarded. This process was repeted twice to obtain the defatted/dehydrated samples.

Total protein extraction: the extraction buffer was: $0.0625 \mathrm{M}$ Tris- $\mathrm{HCl}(\mathrm{pH}:$ 6.8) containing 3\% sodium dodecyl sulfate (SDS) y 2\% 2-mercaptoethanol (2-ME) (Total protein extraction solution). Defatted and dehydrated samples $(30 \mathrm{mg}$ ) were extracted adding $2 \mathrm{~mL}$ of total protein extraction solution and heating the mixture in a water bath at $100^{\circ} \mathrm{C}$ for 5 minutes and subsequently centrifugated at $2500 \mathrm{rpm}$ for 15 minutes. The supernatants (extracts) were stored at $-20^{\circ} \mathrm{C}$ until the analysis.

\subsection{Immunochemical Methods Polyclonal Antiserum (Primary Antibodies)}

Cow's milk polyclonal antiserum was prepared by inoculating NZW rabbits with 100 ug of cow'milk proteins emulsified with complete Freund's adjuvant. A series of four injections $(50 \mathrm{ug})$ of the same antigen in incomplete Freund's adjuvant was administered every 3 weeks. Antibody titres were determined by indirect ELISA. [9].

\subsubsection{Dot Blot}

Three $\mathrm{uL}$ of each extract were placed on a nitrocellulose membrane. The membrane was blocked with $7 \mathrm{~mL}$ of blocking solution (1.2 $\mathrm{g}$ of commercial porcine plasma in $30 \mathrm{~mL}$ of TBS -Tween 20 solution) and incubated for 30 minutes with stirring. The TBS -Tween 20 solution contained $0.05 \mathrm{M}$ Tris, $0.15 \mathrm{M} \mathrm{NaCl}, \mathrm{pH}$ : 7.5 with $0.125 \%$ (v/v) Tween 20.

The primary antibody $(5,8 \mathrm{uL})$ was added to membrane and it was incubated again for 1 hour and 30 minutes with stirring. Subsequently the solution was discarded and the membrane was washed 3 times for 5 minutes each time with $7 \mathrm{~mL}$ of TBS-Tween 20 solution with stirring.

After that $7 \mathrm{~mL}$ of blocking solution and $15 \mathrm{uL}$ of a secondary antibody (Goat anti-rabbit IgG (H+L)-AP Conjugate from BioRad, Catalog Number 170-6518) were added to the membrane. It was incubated for another hour and 30 minutes with stirring and then it was washed 3 times for 5 minutes each time with $7 \mathrm{~mL}$ of TBS-Tween 20 solution with stirring.

The membrane was stained with $7 \mathrm{~mL}$ of AP conjugate substrate kit from Bio Rad (Catalog Number 170-6432) and it was left standing for 7 minutes. Finally it was washed three times for 3 minutes each time with $7 \mathrm{~mL}$ of distilled water with stirring.

The dots were scanned by reflection with Shimadzu Dual - Wavelength Chromatogram Scanner Model CS - 910. A wavelength of maximun absortion of $550 \mathrm{~nm}$ was used. Data acquisition was performed with the program DataApex CSW Chromatography Station Ltd. [10]. In all cases samples were analyzed in duplicate.

The dots of the model systems were scanned in duplicates obtaining the areas of each one. The average of both areas was calculated. The cut off value was considered as the area with significative difference in relation to the 
area of the model system without extrinsic proteins (0 ppm). The model systems with areas higher than the cut off value were considered positive.

\subsubsection{Immunoblotting Electrophoresis}

Protein separation by polyacrylamide slab gel electrophoresis with Laemmli system (SDS-PAGE) was used. [11]

The running gel was prepared with $10 \%$ acrylamide solution in $1.5 \mathrm{M}$ Tris- $\mathrm{HCl}$ containing $0.4 \% \mathrm{SDS}$ ( $\mathrm{pH}: 8.8$ ). The stacking gel was prepared with $3 \%$ solution of acrylamide in $0.5 \mathrm{M}$ Tris- $\mathrm{HCl}$ containing $0.4 \%$ SDS (pH: $6.8)$.

All the model systems and the commercial products were analysed using as controls PDM and DW. An aliquot of the extract of each model system or each commercial meat products $(30 \mathrm{uL})$ was mixed with $15 \mathrm{uL}$ of $50 \%$ glycerol and $15 \mathrm{uL}$ of $0.001 \%$ bromophenol blue in water. An aliquot of the extract of PDM $(10 \mathrm{uL})$ was mixed with 30 $\mathrm{uL}$ of $50 \%$ glycerol and $30 \mathrm{uL}$ of $0.001 \%$ bromophenol blue in water. An aliquot of the extract of DW (5 uL) was mixed with $30 \mathrm{uL}$ of $50 \%$ glycerol and $30 \mathrm{uL}$ of $0.001 \%$ bromophenol blue in water. Five uL of each mixture were load in each well.

Electrophoresis was performed using Tetra Mini Protean cell from BioRad at $180 \mathrm{~V}$ for 45 minutes.

Transfer: Gels, filters, precut membranes and pads were hydrated with the transfer buffer $(25 \mathrm{mM}$ Tris, $192 \mathrm{mM}$ glycine, $20 \% \mathrm{v} / \mathrm{v}$ methanol, $\mathrm{pH} 8.3$ ) for 20 minutes.

The gel sandwich was placed in the cassette, and this one in the transfer module. This module was placed together with a cooling unit in the tank, and the tank was filled with transfer buffer. The transference was performed for 60 minutes at $100 \mathrm{~V}$ and $350 \mathrm{~mA}$, with stirring.

Stain: It was done following the procedure for Dot Blot [10].

All the samples were analyzed in duplicate.

\subsubsection{ELISA}

The detection and quantification of total milk proteins were determined with ELISA using Veratox ${ }^{\circledR}$ Allergen Total Milk from Neogen and Ridascreen ${ }^{\circledR}$ Fast Milk Protein from R-Biopharm. All samples were assayed in duplicate following the protocols of each kit

The detection (DL) and quantification (QL) limits for each kit were: Ridascreen ${ }^{\circledR}$ Fast milk Protein R-Biopharm DL: $0.7 \mathrm{ppm}$ milk protein and QL: $2.5 \mathrm{ppm}$ milk protein with a quantification range of 2.5 - $67.5 \mathrm{ppm}$ milk protein; Veratox ${ }^{\circledR}$ Allergen Total Milk from Neogen DL: 1 ppm milk protein and QL: $2.5 \mathrm{ppm}$ milk protein with a quantification range of $2.5-25$ ppm milk protein. $[12,13]$

\section{Results and Discussion}

\subsection{Model Systems of Raw Meat and Cooked Boneless Ham}

Table 1 shows the results of milk protein detection in model systems of raw meat and in model systems of cooked boneless ham with the addition of 0-5000 ppm PDM, using Dot Blot and Immunoblotting.

Table 1. Milk protein detection in model systems of raw meat and in model systems of cooked boneless ham with the addition of 0-5000 ppm of powder deffated milk (PDM) using Dot Blot and Immunoblotting.

\begin{tabular}{|c|c|c|c|c|}
\hline \multirow{2}{*}{$\begin{array}{l}\text { Raw and cooked model } \\
\text { systems ppm PDM }\end{array}$} & \multicolumn{2}{|l|}{ Dot Blot } & \multicolumn{2}{|l|}{ Immunoblotting } \\
\hline & Raw & Cooked & Raw & Cooked \\
\hline 0 & Negative Area: 21 & Negative Area: 4 & Negative & Negative \\
\hline 10 & Negative Area: 22 & Negative Area: 3 & Negative & Negative \\
\hline 17,5 & Negative Area: 22 & Negative Area: 3 & Negative & Negative \\
\hline 25 & Negative Area: 23 & Negative Area: 4 & Negative & Negative \\
\hline 50 & Negative Area: 24 & Negative Area: 5 & Negative & Negative \\
\hline 100 & Positive Area: 46 & Negative Area: 5 & Negative & Negative \\
\hline 500 & Positive Area: 63 & Negative Area: 8 & Negative & Negative \\
\hline 1000 & Positive Area: 64 & Positive Area: 13 & Positive (caseins) & Positive (caseins) \\
\hline 2000 & Positive Area: 71 & Positive Area: 21 & Positive (caseins) & Positive (caseins) \\
\hline 3000 & Positive Area: 102 & Positive Area: 25 & Positive (caseins) & Positive (caseins) \\
\hline 5000 & Positive Area: 130 & Positive Area: 25 & Positive (caseins) & Positive (caseins) \\
\hline
\end{tabular}

According to the results of Table 1 the detection limit of Dot Blot was 100 ppm PDM in model systems of raw meat and 1000 ppm PDM in model systems of cooked boneless ham. The detection limit of Immunoblotting was 1000 ppm
PDM in both model systems. Two bands of caseins were observed in the model systems with 1000 - 2000 - 30005000 ppm PDM.

Table 2 shows the results of milk protein detection in 
model systems of raw meat and in model systems of cooked boneless ham with the addition of 0-2000 ppm DW

using Dot Blot and Immunoblotting

Table 2. Milk protein detection in model systems of raw meat and in model systems of cooked boneless ham with the addition of 0-2000 ppm of dry whey (DW) using Dot Blot and Immunoblotting.

\begin{tabular}{|c|c|c|c|c|}
\hline \multirow{2}{*}{$\begin{array}{l}\text { Raw and cooked model } \\
\text { systems ppm DW }\end{array}$} & \multicolumn{2}{|l|}{ Dot Blot } & \multicolumn{2}{|l|}{ Immunoblotting } \\
\hline & Raw & Cooked & Raw & Cooked \\
\hline 0 & Negative Area: 3 & Negative Area: 2 & Negative & Negative \\
\hline 10 & Negative Area: 4 & Negative Area: 2 & Negative & Negative \\
\hline 17,5 & Negative Area: 4 & Negative Area: 3 & Negative & Negative \\
\hline 25 & Negative Area: 4 & Negative Area: 3 & Negative & Negative \\
\hline 50 & Negative Area: 5 & Negative Area: 3 & Negative & Negative \\
\hline 100 & Negative Area: 5 & Negative Area: 3 & Negative & Negative \\
\hline 500 & Negative Area: 5 & Positive Area: 6 & Negative & Positive ( $\beta$-lactoglobulin) \\
\hline 1000 & Positive Area: 11 & Positive Area: 7 & Positive ( $\beta$-lactoglobulin) & Positive ( $\beta$-lactoglobulin) \\
\hline 2000 & Positive Area: 15 & Positive Area: 8 & Positive ( $\beta$-lactoglobulin) & Positive ( $\beta$-lactoglobulin) \\
\hline
\end{tabular}

In Table 2 the results show that both methods, Dot Blot and Immunoblotting detected 1000 ppm DW in model systems of raw meat and $500 \mathrm{ppm}$ DW in model systems of cooked boneless ham. Using Immunoblotting it was posible to observe the presence of $\beta$-lactoglobulin's band in the model systems where DW was detected.

Immunoblotting had the advantage that it allowed the observation of characteristic bands corresponding to milk proteins which are recognized by the primary antibodies (caseins or $\beta$-lactoglobulins). In Dot Blot only dots were observed and it was not posible to know if the primary antibody recognizes specific milk proteins or if a nonspecific reaction had happened. As the detection limits of milk proteins in both raw and cooked model systems were high, Immunoblotting would be able to detect the presence of milk proteins, from both PDM and DW, when these were added as ingredients or additives and were not declared in their respective labels. In Argentina the addition of dairy raw materials in meat products is frecuent and unfortunately not always these products are declared in the mandatory list of ingredients $[9,14]$

Table 3 shows the results of the quantification of milk proteins using two ELISA kits in model systems of raw meat and in model systems of cooked boneless ham with the addition of 0-5000 ppm PDM.

Table 3. Results obtained in the quantification ofmilk proteins using two ELISA kits inmodel systems of raw meat andin model systems of cooked boneless ham with the addition of 0-5000 ppm of PDM.

\begin{tabular}{lllll}
\hline \multirow{2}{*}{$\begin{array}{l}\text { Raw and cooked model } \\
\text { systems ppm PDM }\end{array}$} & \multicolumn{2}{l}{ Veratox®Allergen Total Milk, Neogen ppm PDM } & \multicolumn{2}{l}{ Ridascreen® FastMilk Protein, R-biopharm ppm milk protein } \\
\cline { 2 - 5 } & Raw & Cooked & Raw & Cooked \\
\hline 0 & $<2.5$ & $<2.5$ & $<2.5$ & 3.5 \\
10 & 2.7 & $<2.5$ & 2.8 & 3.0 \\
17,5 & 4.6 & 2.5 & 3.6 & 6.5 \\
25 & 5.9 & $<.5$ & 5.0 & 10.1 \\
50 & 11.6 & 11.0 & 12.8 \\
100 & 24.2 & 5.7 & 14.8 & $>67.5$ \\
500 & $>25.0$ & 15.7 & 32.7 & $>67.5$ \\
1000 & $>25.0$ & 16.5 & $>67.5$ & $>67.5$ \\
2000 & $>25.0$ & 20.0 & $>67.5$ & $>67.5$ \\
3000 & $>25.0$ & $>25.0$ & $>67.5$ & $>67.5$ \\
5000 & $>25.0$ & $>25.0$ & $>67.5$ & \\
\hline
\end{tabular}

In Table 3 the results show that the Neogen kit detected from 10 ppm PDM in model systems of raw meat and from 100 ppm PDM in model systems of cooked boneless ham. The R-Biopharm kit detected from 10 ppm PDM in both model systems. There was a great difference between the quantitative results of both kits and theoretical values.
Table 4 shows the results of the quantification of whey proteins using two ELISA kits in model systems of raw meat and in model systems of cooked boneless ham with the addition of 0-2000 ppm DW. 
Table 4. Results obtained in the quantification of whey proteins using two ELISA kits in model systems of raw meat andin model systems of cooked boneless ham with the addition of 0-2000 ppm of DW.

\begin{tabular}{lllll}
\hline \multirow{2}{*}{$\begin{array}{l}\text { Raw and cooked model } \\
\text { systems ppm DW }\end{array}$} & \multicolumn{2}{l}{ Veratox® AllergenTotal Milk, Neogen ppm PDM } & \multicolumn{2}{l}{$\begin{array}{l}\text { Ridascreen® Fast Milk Protein, R-biopharm ppm milk } \\
\text { protein }\end{array}$} \\
\cline { 2 - 5 } & Raw & Cooked & Raw & Cooked \\
\hline 0 & $<2.5$ & $<2.5$ & $<2.5$ & $<2.5$ \\
10 & 5.0 & 5.7 & 8.2 & 11.6 \\
17,5 & 8.9 & 6.2 & 17.5 & 20.0 \\
25 & 9.4 & 7.5 & 36.0 & $>1.0$ \\
50 & 12.0 & N/A & $>67.5$ & $>67.5$ \\
100 & 17.0 & 18.3 & $>67.5$ \\
500 & 22.2 & 24.0 & $>67.5$ \\
1000 & 23.7 & $>25.0$ & $>67.5$ \\
\hline
\end{tabular}

N/A: not analyzed

In Table 4 the results show that both kits (Neogen and R-Biopharm) detected from 10 ppm DW in model systems of raw meat and in model systems of cooked boneless ham. In model systems with DW is difficult to evaluate the correct quantification of this milk product because the results are reported as ppm of milk protein (R-Biopharm) or as ppm of PDM (Neogen).

Neogen kit was more sensitive detecting PDM in raw model systems (10 ppm PDM) compared to cooked model systems (100 ppm PDM).On the other cases the sensitivity was similar for raw and cooked model systems (10 ppm PDM, 10 ppm DW).

The results of the raw model systems were always higher than those obtained in cooked model systems using the Neogen Kit. This was not observed when DW was added. The heat treatment affected the results obtained with this particular kit when the proteins derived from PDM, but not when they derived from DW. These differences were not observed with the R-Biopharm kit which responds in the same way with and without heat treatment.

\subsection{Commercial Meat Products}

Table 5 shows the results obtained in the quantification of milk proteins using Dot Blot, Immunoblotting and two ELISA kits in commercial meat products. The description of each product and the ingredient list present in each of the samples are shown in Table 5.

Samples F, JC, MP and MCC did not declare dairy products and the results for them were negative with all the methods used. Samples FL, S and LC declared milk products and FSL declared whey in their labels and all the methods used yielded positive results for these ingredients. In the particular case of $\mathrm{CH}, \mathrm{MPA}$ and M, all the methods used in this work detected milk proteins although they were not declared in the labels of these products.

In a previous study using ELISA $\beta$-lactoglobulin kit and ELISA casein kit from R-Biopharm milk proteins had been detected in MPA [15]

Evidently, MPA contained milk eventhough this ingredient was not declared in the label. In the same study ß-lactoglobulin was detected in $\mathrm{CH}$ (that did not declared milk) and LC (that declared milk) with the ELISA B-lactoglobulin kit from R-Biopharm. In both samples caseins were not detected using the ELISA casein kit from R-Biopharm. Using Immunoblotting both samples presented B-lactoglobulin's band. These results allowed us to conclude that these samples really contained whey and did not contain other dairy product [15]

The low values of ppm PDM obtained with the Neogen kit in the samples LC (14,2 ppm PDM), CH (15.8 ppm PDM) and MPA (13.6 ppm PDM) and with the R-Biopharm kit in the sample M (15.2 ppm milk protein) are in accordance with the low results obtained in model systems using ELISA. These ELISA kits allowed the detection of milk in these model systems but the values that were obtained differ from the theoretical values of these samples (Table 3). As it was previously mentioned the detection limit of Immunoblotting and Dot Blot in raw model systems with DW and cooked model systems with PDM is $1000 \mathrm{ppm}$ of DW or PDM, respectively. If the samples MPA, CH, LC and M really contained such low values of milk proteins or its derivatives Dot Blot and Immunoblotting would have been negative. The results of Neogen Kitand R-Biopharm kit suggest that some ELISA kits may not allow to quantify real concentration of milk proteins.

\section{Conclusions}

ELISA methods are more sensitive for the detection of milk proteins than Dot Blot and Immunoblotting. The R-Biopharm kit is the most sensitive kit for the analysis of these raw and cooked meat products. However Immunoblotting can be useful for the detection of milk proteins if it is suspected that they were added as ingredients or additives. The Immunoblotting allows verifying the presence of caseins and / or $\beta$-lactoglobulin in meat products. In contrast, the use of an ELISA kit is more appropriate to verify a possible cross-contamination. 
Table 5. Results obtained in the quantification of milk proteins using Dot Blot, Immunoblotting and two ELISA kits in commercial meat products.

\begin{tabular}{|c|c|c|c|c|c|c|}
\hline Samples & Product Description & $\begin{array}{l}\text { Declared Protein } \\
\text { Ingredients }\end{array}$ & DOT BLOT & Inmunoblotting & $\begin{array}{l}\text { Veratox }{ }^{\circledR} \text { Allergen } \\
\text { Total Milk, Neogen } \\
\text { (ppm PDM) }\end{array}$ & $\begin{array}{l}\text { Ridascreen }{ }^{\circledR} \text { Fast Milk } \\
\text { Protein, R-biopharm (ppm } \\
\text { milk protein) }\end{array}$ \\
\hline $\mathrm{F}$ & $\begin{array}{l}\text { Porcine products } \\
\text { labelled "Fiambre de } \\
\text { cerdo" }\end{array}$ & $\begin{array}{l}\text { Porcine meat, } \\
\text { collagen and } \\
\text { hidrolized gellatine. }\end{array}$ & $\begin{array}{l}\text { Negative } \\
\text { Area: } 4\end{array}$ & Negative & $<2.5$ & $<2.5$ \\
\hline $\mathrm{JC}$ & Boneless ham & Porcine meat & $\begin{array}{l}\text { Negative } \\
\text { Area: } 3\end{array}$ & Negative & $<2.5$ & $<2.5$ \\
\hline MP & Mortadella & $\begin{array}{l}\text { Bovine meat, } \\
\text { porcine meat and soy } \\
\text { protein isolated }\end{array}$ & $\begin{array}{l}\text { Negative } \\
\text { Area: } 3\end{array}$ & Negative & $<2.5$ & $<2.5$ \\
\hline $\mathrm{MCC}$ & Hamburguers & $\begin{array}{l}\text { Bovine meat, soy } \\
\text { proteins }\end{array}$ & $\begin{array}{l}\text { Negative } \\
\text { Area: } 3\end{array}$ & Negative & $<2.5$ & $<2.5$ \\
\hline $\mathrm{FL}$ & $\begin{array}{l}\text { Porcine products } \\
\text { labelled "Fiambre de } \\
\text { cerdo" }\end{array}$ & $\begin{array}{l}\text { Porcine meat, } \\
\text { collagen,hidrolized } \\
\text { gellatine and powder } \\
\text { deffated milk }\end{array}$ & $\begin{array}{l}\text { Positive } \\
\text { Area: } 14\end{array}$ & Positive (Caseins) & $>25.0$ & $>67.5$ \\
\hline S & Sausage & $\begin{array}{l}\text { Bovine meat, } \\
\text { porcine meat, soy } \\
\text { protein isolate, } \\
\text { powder milk. }\end{array}$ & $\begin{array}{l}\text { Positive } \\
\text { Area: } 14\end{array}$ & Positive (Caseins) & N/A & $>67.5$ \\
\hline LC & Dry sausage & Bovine meat, milk & $\begin{array}{l}\text { Positive } \\
\text { Area: } 14\end{array}$ & $\begin{array}{l}\text { Positive } \\
\text { (B-lactoglobulin) }\end{array}$ & 14.2 & N/A \\
\hline FSL & $\begin{array}{l}\text { Porcine product } \\
\text { labelled"fiambre de } \\
\text { cerdo cocido" }\end{array}$ & $\begin{array}{l}\text { Porcine meat, } \\
\text { collagen,hidrolized } \\
\text { gellatine and whey }\end{array}$ & $\begin{array}{l}\text { Positive } \\
\text { Area: } 13\end{array}$ & $\begin{array}{l}\text { Positive } \\
\text { (ß-lactoglobulin) }\end{array}$ & $>25.0$ & $>67.5$ \\
\hline $\mathrm{CH}$ & Dry sausage & $\begin{array}{l}\text { Bovine meat, } \\
\text { porcine meat. }\end{array}$ & $\begin{array}{l}\text { Positive } \\
\text { Area: } 14\end{array}$ & $\begin{array}{l}\text { Positive } \\
\text { (ß-lactoglobulin) }\end{array}$ & 15.8 & $>67.5$ \\
\hline MPA & Mortadella & $\begin{array}{l}\text { Bovine meat, } \\
\text { porcine meat. }\end{array}$ & $\begin{array}{l}\text { Positive } \\
\text { Area: } 13\end{array}$ & $\begin{array}{l}\text { Positive } \\
\text { (caseins, } \\
\text { ß-lactoglobulin) }\end{array}$ & 13.6 & N/A \\
\hline M & Black pudding & $\begin{array}{l}\text { Bovine blood, } \\
\text { pigskin, soy protein } \\
\text { isolate. }\end{array}$ & $\begin{array}{l}\text { Positive } \\
\text { Area:13 }\end{array}$ & $\begin{array}{l}\text { Positive } \\
\text { (caseins) }\end{array}$ & N/A & 15.2 \\
\hline
\end{tabular}

N/A: not analyzed

\section{Acknowledgements}

The authors are grateful to VAES S.R.L. for bringing samples of known composition for analysis.

This work was partially financiated by the Buenos Aires University (UBACyT 20020120100175BA)

\section{References}

[1] Taylor, S. 2006. The nature of food allergy. In Stef J. Koppelman, Hefle Sue L., (Eds). Detecting allergens in food.(pp. 3-17). Abington, Cambridge. Woodhead Publishing Limited, England.

[2] Hideaki, T., Masumi, K. \& Yasuo, N. 2001. Allergens in major crops. Nutrition Research. 21: 925.

[3] Lehrer, S.B., Ayuso, R. \& Reese, G. 2002.Current Understanding of Food Allergens. Ann. N.Y. Acad. Sci. 96: 69.

[4] Poms, R., Klein, C. \& Anklam, E. 2004. Methods for analysis in food allergen: a review. Food Additives and Contaminants.21 (1): 1 .
[5] Diaz-Amigo, C., Popping, B. 2010. Detection of food allergens. In Popping, B., Diaz-Amigo, C., Hoenicke, K., (Eds). Molecular Biological and Immunological Techniques and Applications for Food Chemists. (pp: 175-198) 1st ed. New Jersey. John Wiley \& Sons.

[6] López, L.B., Greco, C.B., Ronayne de Ferrer, P. \& Valencia, M.E. 2006.Identification of extrinsic proteins in boneless cooked ham by SDS-PAGE: detection level in model systems. Archivos Latinoamericanos de Nutrición. 56 (3): 282.

[7] Argentine Food Code, 2014 http://www.anmat.gov.ar/alimentos/codigoa/Capitulo_V.pdf. Access: 16/08/14.

[8] López, L.B., Binaghi, M.J. Greco, C.B., Mambrín, M.C., Cellerino, K. \& Valencia, M.E. 2010. Salted sausage and dried sausages: detection by electrophoresis of meat species and extrinsic proteins aggregate. Diaeta. 28 (131): 7.

[9] Rozenfeld, P., Docena, G., Añon, M. \& Fossati, C. 2002. Detection and identification of a soy protein component that cross-reacts with caseins from cow's milk. Clinical \& Experimental Immunology. 130 (1): 49. 
[10] Cellerino, K. 2011.Control methodology for the analysis of allergenic proteins of soy andmilk in meat products. MSc Thesis. Buenos Aires Argentina: MITA - International Master in Food Technology- Agronomy Faculty, Buenos Aires University, and Università degli Studi di Parma -Italia-.

[11] Laemmli, U.K. 1970. Cleavage of structural proteins during the assembly of the head bacteriophage t4. Nature. 227: 680 .

[12] Veratox ${ }^{\circledR}$ Total Milk (Code: 8470). Neogen, 2013. http://www.neogen.com/FoodSafety/pdf/ProdInfo/V-TotalM ilk.pdf . Access: 26/08/2014.

[13] RIDASCREEN® Fast Milk protein (Art. Nro.: R4652).R-Biopharm.2013.

http://www.R-Biopharm.com/products/food-feed-analysis/al lergens/milk/item/ridascreenfast-milk. Access: 26/08/2014.
[14] Cellerino, K., Binaghi, M.J., Cagnasso, C.E., Mambrin, M.C., Docena, G., Polenta, G., Valencia, M.E. \& López, L.B. 2012. Use of SDS-PAGE and Immunochemichal methods for milk allergens detection in meat products. La Industria Cárnica Latinoamericana.176: 58.

[15] Cellerino, K., Binaghi, M.J., Cagnasso, C.E., Mambrín, M.C., Docena, G., Polenta, G., Valencia, M.E. \& López, L.B. 2011. Comparationof SDS-PAGE and blotting for de detection of milk proteins in meat products. Full paper: 4Cellerino 1. (pp. 1-5). XIII CYTAL Congress-AATA. 